\title{
PENGARUH TINGKAT INFLASI TERHADAP NILAI TUKAR RUPIAH (Studi Pada Bank Indonesia Periode Tahun 2011-2015)
}

\author{
Yati Wijayanti \\ Mahasiswa Prodi Pendidikan Ekonomi \\ anty.wijaya05@gmail.com \\ Sudarmiani \\ Dosen Prodi Pendidikan Ekonomi FPIPS IKIP PGRI Madiun \\ aniwidjiati@yahoo.com
}

\begin{abstract}
This study aimed to analyze the influence of the inflation rate of the Rupiah. Population and samples used in this study are all monthly time series data rate of inflation and the Rupiah during the period January 2011-December 2015 as many as 60. The data used are secondary data obtained from the official website of Bank Indonesia (www.bi.co.id). The analytical method used in this study is a simple linear regression analysis. The result of the coefficient of determination ( $r 2)$ which shows that the percentage of the effect of the inflation rate to changes in the rupiah exchange rate of 7,9\%. From the calculations, the equation $Y=3.941+0,073 X$, it can be concluded that the level of inflation is positive and significant effect on the rupiah.
\end{abstract}

\section{Keywords : Inflation, Exchange Rates}

\begin{abstract}
Abstrak
Penelitian ini bertujuan untuk menganalisis pengaruh tingkat inflasi terhadap nilai tukar Rupiah. Populasi dan sampel yang digunakan dalam penelitian ini adalah seluruh data time series bulanan tingkat inflasi dan nilai tukar Rupiah selama periode Januari 2011Desember 2015 yaitu sebanyak 60 yang diperoleh dari website resmi Bank Indonesia (www.bi.co.id). Metode analisis yang digunakan dalam penelitian ini adalah teknik analisis regresi linier sederhana. Hasil uji koefisien determinasi $\left(\mathrm{r}^{2}\right)$ yang dilakukan menunjukkan bahwa persentase pengaruh tingkat inflasi terhadap perubahan nilai tukar Rupiah sebesar 7,9\%. Dari hasil perhitungan diperoleh persamaan $Y=3,941+0,073 \mathrm{X}$, maka dapat diambil kesimpulan yaitu tingkat inflasi berpengaruh positif secara signifikan terhadap nilai tukar Rupiah.
\end{abstract}

Kata kunci: Tingkat Inflasi, Nilai Tukar

\section{PENDAHULUAN}

Pada era globalisasi saat ini gerakan MEA mendorong terjadinya perdagangan internasional. Perdagangan internasional yang terjadi antara satu negara dengan negara lain menimbulkan terjadinya hubungan perekonomian yang semakin terikat melalui kegiatan ekspor dan impor. Dimana suatu negara melakukan ekspor agar dapat menembus pasar internasional dalam memasarkan produknya dan melakukan impor untuk memperoleh barang dengan biaya yang rendah.

"Perdagangan internasional yang 
semakin mudah dan semakin berkurangnya hambatan dalam melakukan perdagangan internasional mengakibatkan peningkatan volume dan nilai perdagangan internasional" (Kartikaningtyas dkk, 2014: 1). Sehingga dalam melakukan transaksi perdagangan internasional diperlukan mata uang yang telah disepakati oleh negara yang melakukan ekspor maupun impor sebagai alat pembayaran. Sehingga untuk menunjang kegiatan perdagangan internasional dengan negara lain, suatu negara harus mengubah mata uang yang akan digunakan ke mata uang yang telah disepakati.

"Perubahan nilai tukar ini menyebabkan terjadinya risiko nilai tukar yang akan berpengaruh langsung terhadap perkembangan harga barang dan jasa di dalam negeri. Adanya nilai tukar mata uang tersebut berdampak pada apresiasi dan depresiasi mata uang" (Puspitaningrum dkk, 2014:1). Dalam Jeff Madura (2006:123) dijelaskan "apresiasi merupakan peningkatan suatu mata uang sedangkan depresiasi adalah penurunan nilai pada suatu mata uang”. Sehingga kita akan sulit memprediksi fluktuasi kurs mata uang di masa yang akan datang. Madura (2006:128) menyebutkan perubahan nilai tukar mata uang dipengaruhi oleh beberapa faktor, antara lain tingkat inflasi relatif, suku bunga relatif, tingkat pendapatan relatif, pengendalian pemerintah, dan prediksi pasar.

Inflasi merupakan salah satu faktor yang sangat besar pengaruhnya kepada kurs pertukaran valuta asing. Inflasi yaitu suatu kondisi dimana terjadi kenaikan harga barang-barang yang tidak sesaat dan berlangsung secara terus-menerus. "Inflasi adalah proses kenaikan harga-harga umum barang-barang secara terus-menerus" (Nopirin, 2013:25). Boediono (2013: 161) menjelaskan pengertian inflasi adalah kecenderungan dari harga-harga untuk menaik secara umum dan terus-menerus. Kenaikan harga dari satu atau dua barang saja tidak disebut inflasi, kecuali bila kenaikan tersebut meluas kepada (atau mengakibatkan kenaikan) sebagian besar dari harga barangbarang lain. Syarat adanya kecenderungan menaik yang terus-menerus juga perlu diingat.

Inflasi yang berlaku pada umumnya cenderung untuk menurunkan nilai suatu valuta asing. Kecenderungan seperti ini wujud disebabkan efek inflasi berikut: (i) inflasi menyebabkan harga-harga di dalam negri lebih mahal dari harga-harga di luar negri dan oleh sebab itu inflasi berkecenderungan menambah impor, (ii) inflasi menyebabkan harga-harga barang ekspor menjadi lebih mahal, oleh karena itu inflasi berkecenderungan mengurangi ekspor. Keadaan (i) menyebabkan permintaan ke atas valuta asing bertambah, dan keadaan (ii) menyebabkan penawaran ke atas valuta asing berkurang; maka harga valuta asing akan bertambah, ini berarti harga mata uang negara yang mengalami inflasi melorot (Sadono Sukirno, 2013:402).

Tingkat harga yang terjadi di setiap negara disesuaikan untuk menyeimbangkan jumlah uang yang beredar dan jumlah permintaan uang. Karena nilai tukar nominal bergantung pada tingkat harga, nilai tukar tersebut juga bergantung pada persediaan dan permintaan uang di setiap negara. Ketika bank sentral di setiap negara meningkatkan jumlah uang yang beredar dan menyebabkan tingkat harga meningkat, hal tersebut juga menyebabkan mata uang negara tersebut terdepresiasi terhadap mata uang lain di dunia. Dengan kata lain, ketika bank sentral mencetak uang dalam jumlah banyak, uang kehilangan nilainya untuk membeli barang dan jasa, serta untuk membeli mata uang negara lain (Gregory N. Mankiw, 2013:198).

Berdasarkan teori Keynes (Boediono, 2013: 169) inflasi terjadi karena suatu masyarakat ingin hidup di luar batas kemampuan ekonominya. Dimana keinginan mereka 
melebihi jumlah barang atau jasa yang dapat dipenuhi oleh masyarakat itu sendiri. Sehingga timbul inflationary gap karena permintaan total melebihi jumlah barang yang tersedia, maka harga-harga akan naik.

Menurut Jeff Madura (2006:128) "perubahan tingkat inflasi relatif dapat mempengaruhi aktivitas perdagangan internasional, yang akan mempengaruhi permintaan dan penawaran suatu mata uang dan karenanya mempengaruhi kurs nilai tukar".

Perubahan nilai tukar yang berubahubah setiap saat ini dapat menyebabkan terjadinya depresiasi dan apresiasi terhadap mata uang itu sendiri. Dalam Jeff Madura (2006: 123) dijelaskan "apresiasi merupakan peningkatan suatu mata uang sedangkan depresiasi adalah penurunan nilai pada suatu mata uang".

Jika inflasi suatu negara meningkat, permintaan atas mata uang negara tersebut akan turun karena ekspor negara tersebut turun (disebabkan harga yang lebih tinggi). Selain itu, konsumen dan perusahaan dalam negara tersebut cenderung meningkatkan impor mereka. Kedua hal tersebut akan menekan inflasi tinggi pada mata uang suatu negara. Tingkat inflasi antar negara berbeda, sehingga pola perdagangan internasional dan nilai tukar akan berubah sesuai dengan inflasi tersebut. Salah satu teori terkenal dan kontroversial dalam keuangan internasional adalah teori paritas daya beli (purchasing power parity), yang berupaya untuk melihat hubungan antara inflasi dengan nilai tukar secara kuantitatif(Jeff Madura, 2006: 299).

M. Faisal (2001: 41) mengatakan PPP merupakan ekspektasi perubahan kurs karena adanya perbedaan ekspektasi tingkat inflasi (kurs suatu mata uang dengan mata uang lainnya ditentukan oleh purchasing power dari masing-masing mata uang yang diperbandingkan sehingga nilai tukar atau kurs tersebut akan bergerak pada arah yang ditentukan oleh perbedaan tingkat inflasi dari negara-negara tersebut.

Teori paritas daya beli (purchasing power parity) menyatakan bahwa satu unit mata uang tertentu harus mampu membeli barang dalam jumlah yang sama di semua negara. Banyak ekonom percaya bahwa paritas daya beli menggambarkan daya yang menentukan nilai tukar dalam jangka panjang. Teori paritas daya beli didasarkan pada prinsip yang disebut dengan hukum satu harga (the law of one price). Hukum ini menyatakan bahwa sebuah barang harus dijual dengan harga yang sama di semua lokasi. Jika tidak, akan ada peluang keuntungan yang tidak tereksploitasi (Gregory N. Mankiw, 2013: 196-197).

Hukum satu harga menjelaskan hubungan antara nilai tukar dan harga komoditas. Hukum ini menyatakan bahwa komoditas yang sama akan memiliki harga yang (reatif) sama pula, meskipun dijual di tempat yang berbeda. Adanya perbedaan harga komoditas akan menciptakan peluang untuk melakukan arbitrase. Arbitrase dilakukan dengan membeli komoditas di tempat yang lebih murah dan menjualnya di tempat yang lebih mahal. Adanya arbitrase pada akhirnya akan menaikkan harga komoditas di tempat yang lebih murah dan menurunkan harga di tempat yang lebih mahal. Pada akhirnya, harga-harga komoditas di berbagai tempat akan relatif sama. Setiap perbedaan harga komoditas hanya disebabkan oleh adanya biaya transportasi, proteksi, dan biaya-biaya transaksi lainnya (Yuliati dan Handoyo, 2005: 101).

Mata uang yang digunakan sebagai pembanding dalam tukar menukar mata uang dalam penelitian ini yaitu Dollar Amerika Serikat (US Dollar). Hal ini dikarenakan Dollar Amerika adalah mata uang yang digunakan dalam perdagangan internasional yang kuat. Selain itu, Amerika merupakan negara yang melakukan kerjasama yang perdagangan Indonesia secara dominan. 
Berdasarkan dari latar belakang penelitian, identifikasi dan batasan masalah tersebut, maka dapat dirumuskan masalah dalam penelitian yaitu: Bagaimana pengaruh tingkat inflasi terhadap nilai tukar Rupiah?

Tujuan dari penelitian ini adalah untuk menganalisis pengaruh tingkat inflasi terhadap nilai tukar Rupiah.

Dari hasil penelitian Zainul Muchlas (2015) yang berjudul "Faktor-Faktor Yang Mempengaruhi Kurs Rupiah Terhadap Dolar Amerika Pasca Krisis (2000-2010)" dapat diketahui bahwa secara simultan inflasi, tingkat suku bunga, jumlah uang yang beredar, dan BOP secara bersama-sama berpengaruh terhadap pergerakan rupiah terhadap dolar Amerika. Secara parsial inflasi, tingkat suku bunga, jumlah uang yag beredar, BOP juga terbukti berpengaruh terhadap pergerakan rupiah terhadap dolar Amerika.

Inflasi merupakan salah satu faktor yang mempengaruhi nilai tukar. Sehingga inflasi dan tukar memiliki hubungan yang sangat erat di antara keduanya. Perubahan pada tingkat inflasi relatif dapat mempengaruhi aktivitas perdagangan internasional yang akan mempengaruhi permintaan dan penawaran suatu mata uang dan karenanya mempengaruhi kurs nilai tukar (Madura, 2006: 128).

Jeff Madura (2006: 299) menjelaskan hubungan antara inflasi dan nilai tukar secara lebih rinci yaitu:

Jika inflasi suatu negara meningkat, permintaan atas mata uang negara tersebut akan turun karena ekspor negara tersebut juga turun. Hal ini disebabkan karena harga pada negara tersebut lebih tinggi dibandingkan dengan harga di luar negeri. Selain itu, konsumen dan perusahaan dalam negara tersebut cenderung meningkatkan impornya. Kedua hal tersebut akan menekan inflasi tinggi pada mata uang suatu negara. Tingkat inflasi antar negara berbeda, sehingga pola perdagangan internasional dan nilai tukar akan berubah sesuai dengan inflasi tersebut. Salah satu teori yang memperlihatkan hubungan antara inflasi dengan nilai tukar secara kuantitatif yaitu teori paritas daya beli (purchasing power parity-PPP).

Perubahan nilai tukar yang berubahubah setiap saat ini dapat menyebabkan terjadinya depresiasi dan apresiasi terhadap mata uang itu sendiri. Dalam Jeff Madura (2006: 123) dijelaskan "apresiasi merupakan peningkatan suatu mata uang sedangkan depresiasi adalah penurunan nilai pada suatu mata uang".

Agus Sartono (2003: 143) menjelaskan bahwa dalam bentuk absolut PPP tingkat harga penyesuaian seharusnya sama di seluruh dunia. Dengan asumsi bahwa perdagangan bebas akan menyamakan harga barang pada semua negara, meskipun kesempatan untuk melakukan arbitrase masih terbuka lebar. Bentuk absolut PPP mengesampingkan pengaruh perdagangan bebas pada biaya transportasi, tarif, kuota, dan berbagai macam pembatasan serta diferensiasi produk.

Jeff Madura (2006: 299-300) juga mengemukakan bahwa bentuk absolut PPP didasarkan atas asumsi bahwa tidak terdapat hambatan internasional, pelanggan akan merubah permintaan mereka ke tempat yang lebih rendah. Bentuk ini menyatakan harga dari sejumlah produk yang sama pada dua negara berbeda seharusnya setara jika diukur dengan mata uang yang sama. Permintaan akan berubah sehingga harga produk di kedua negara akan menyesuaikan menjadi sama.

"Bentuk relatif paritas daya beli menjelaskan terbentuknya nilai tukar antar mata uang dengan melihat laju inflasi di berbagai negara" (Yuliati dan Prasetyo, 2005: 104).

"Bentuk relatif PPP mempertimbangkan kemungkinan pasar yang tidak sempurna seperti biaya transportasi, bea masuk, dan kuota. Karena adanya ketidaksempurnaan 
pasar, maka harga sejumlah produk pada negara yang berbeda tidak selalu sama jika diukur dalam mata uang yang sama. Namun bentuk relatif PPP menyatakan bahwa tingkat perubahan harga barang kurang lebih akan sama jika diukur dengan mata uang yang sama selama biaya transportasi dan batasan perdagangan lainnya tidak berubah" (Madura, 2006: 300).

Teori paritas daya beli (purchasing power parity-PPP) merupakan teori yang menjelaskan hubungan antara tingkat inflasi dengan tingkat nilai tukar yaitu ekspektasi perubahan nilai tukar yang disebabkan oleh ekspektasi perubahan tingkat inflasi yang ditentukan oleh purchasing power mata uang suatu negara dibandingkan dengan mata uang negara lain. Terdapat dua bentuk PPP yaitu bentuk absolut PPP dan bentuk relatif PPP.

Murni dalam Roshinta Puspitaningrum (2014: 14) mendefinisikan laju inflasi merupakan kenaikan tingkat harga secara umum untuk berbagai jenis produk dalam rentang waktu tertentu misalnya per bulan, per triwulan atau per tahun. Secara garis besar inflasi terjadi pada kenaikan harga dan dalam waktu yang lama. Indikator yang sering digunakan untuk mengukur tingkat inflasi adalah Indeks Harga Konsumen (IHK). Laju atau tingkat inflasi dapat dihitung dengan rumus:

Laju inflasi $=\underline{\mathrm{IHKt}-\mathrm{IHK}(\mathrm{t}-1)} \times 100 \%$ $\operatorname{IHK}(\mathrm{t}-1)$

Sumber : Murni (2006:41)

Keterangan :

IHKt : Indeks harga konsumen tahun tertentu $(\mathrm{t})$

IHK(t-1) : Indeks harga konsumen dari 1 tahun sebelum $(\mathrm{t})$

Berdasarkan permasalahan dalam penelitian ini, maka dapat dibuat kerangka berfikir sebagai berikut:

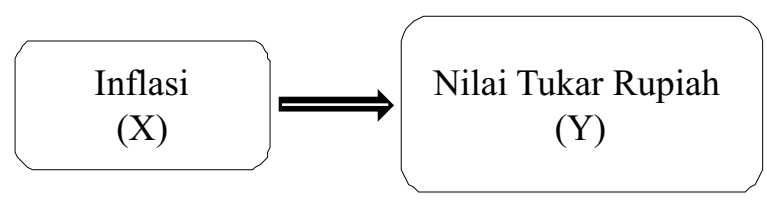

\section{METODE PENELITIAN}

\section{Desain Penelitian}

"Desain penelitian merupakan rencana tentang cara mengumpulkan dan menganalisis data agar dapat dilaksanakan secara ekonomis serta serasi dengan tujuan penelitian itu" (Nasution, 2012: 23). Untuk itu dalam menyelesaikan penelitian ini perlu digunakan cara atau metode yang tepat dipertanggungjawabkan secara ilmiah. Penelitian ini termasuk penelitian penjelasan atau explanatory yaitu penelitian yang menjelaskan hubungan kausal antara variabel-variabel melalui pengujian hipotesis. Menurut Singarimbun dalam Roshinta Puspitaningrum (2014: 40) "penelitian penjelasan atau explanatory adalah penelitian yang menyoroti hubungan antara variabel penelitian dan menguji hipotesa yang telah dirumuskan sebelumnya".

Metode yang digunakan dalam penelitian ini adalah metode kuantitatif. Metode kuantitatif yaitu metode penelitian yang berlandaskan pada filsafat positivisme, digunakan untuk meneliti pada populasi atau sampel tertentu, pengumpulan data menggunakan instrumen penelitian, analisis data bersifat kuantitatif atau statistik, dengan tujuan untuk menguji hipotesis yang telah ditetapkan (Sugiyono, 2013: 11).

Penelitian ini menggunakan metode kuantitatif yang bertujuan untuk menguji hipotesis yang dirumuskan berdasarkan penelitian terdahulu serta untuk mengetahui hubungan antara variabel bebas dan variabel terikat.

Penelitian ini dilakukan untuk menguji pengaruh tingkat inflasi terhadap 
nilai tukar rupiah dimana datanya diperoleh dari website Bank Indonesia (www.bi.go.id) karena Bank Indonesia menyediakan data-data yang dibutuhkan dalam penelitian. Berdasarkan penjelasan Undang-undang No. 23 Tahun 1999 Bank Indonesia sebagai bank sentral mempunyai tujuan tunggal yaitu mencapai dan memelihara kestabilan nilai rupiah dan tidak melaksanakan fungsi atau kegiatan intermediasi seperti halnya bank umum lainnya.

\section{Populasi, Sampel, dan Teknik Peng- ambilan Sampel}

Populasi yang digunakan dalam penelitian ini adalah seluruh data time series bulanan tingkat inflasi dan nilai tukar Rupiah selama periode 2011-2015 yaitu sebanyak 60. Pengambilan sampel dalam penelitian ini menggunakan metode sampling jenuh. Berdasarkan teknik pengambilan sampel tersebut, diperoleh jumlah sampel (n) dari data time series bulanan (1 tahun $=12$ bulan) selama periode Januari 2011 - Desember 2015, yaitu sebanyak 60 sampel (12 bulan x 5 tahun).

\section{Teknik Pengumpulan Data}

Dalam penelitian ini, teknik pengumpulan data sekunder dilakukan adalah dengan dokumenter. Dokumen yang digunakan dalam penelitian ini merupakan data tingkat inflasi dan data nilai tukar Rupiah terhadap Dollar Amerika Serikat periode Januari 2011Desember 2015 yang diperoleh dari website resmi Bank Indonesia (www.bi.go.id).

\section{Teknik Analisis Data}

Analisis data dalam penelitian ini menggunakan program SPSS for windows versi 22.0. Analisis data yang digunakan dalam penelitian ini adalah:
1) Pengujian Asumsi Klasik

Pengujian asumsi klasik ini dimaksudkan untuk memastikan bahwa model yang diperoleh benar-benar memenuhi asumsi dasar dalam analisis regresi linear sederhana yang meliputi asumsi normalitas, tidak terjadi autokorelasi, dan tidak terjadi heteroskedastisitas.

a) Normalitas

Imam Ghozali (2011: 160) mengemukakan bahwa "uji normalitas bertujuan untuk menguji apakah dalam model regresi, variabel pengganggu atau residual memiliki distribusi normal". Salah satu cara termudah untuk melihat normalitas residul adalah dengan melihat grafik histogram yang membandingkan antara data observasi dengan distribusi yang mendekati distribusi normal yang akan membentuk garis lurus diagonal. Oleh sebab itu, dalam penelitian ini pengujian normalitas menggunakan analisis grafik. Dimana dasar pengambilan keputusannya yaitu:

1) Jika data menyebar di sekitar garis diagonal dan mengikuti arah garis diagonal atau grafik histogramnya menunjukkan pola ditribusi normal, maka model regresi memenuhi asumsi normalitas.

2) Jika data menyebar jauh dari diagonal dan/atau tidak mengikuti arah garis diagonal atau grafik histogram tidak menunjukkan pola distribusi normal, maka model regresi tidak memenuhi asumsi normalitas.

b) Autokorelasi

Uji autokorelasi bertujuan untuk menguji apakah dalam model regresi linier ada korelasi antara 
kesalahan pengganggu pada periode $\mathrm{t}$ dengan kesalahan pengganggu pada periode t-1 (sebelumnya). Jika terjadi korelasi, maka dinamakan ada problem autokorelasi. Autokorelasi muncul karena observasi yang berurutan sepanjang waktu berkaitan satu sama lainnya. Hal ini sering ditemukan pada data time series. Model regresi yang baik adalah regresi yang bebas dari autokorelasi.

c) Heteroskedastisitas

Tujuan dari adanya uji heterokedastisitas yaitu untuk menguji apakah dalam model regresi terjadi ketidaksamaan variance dari residual satu pengamatan ke pengamatan lain. Jika variance dari residual seluruh pengamatan tetap, maka disebut homokedastisitas dan jika berbeda maka disebut heterokedastisitas. Model regresi yang baik adalah yang homokedastisitas atau tidak terjadi heterokedastisitas (Imam Ghozali, 2011: 139).

Ada atau tidaknya heterokedastisitas dideteksi dengan melihat ada tidaknya pola tertentu pada grafik scatter plot antara SRESID dan ZPRED dimana sumbu $Y$ adalah $Y$ yang telah diprediksi, dan sumbu $\mathrm{X}$ adalah residual yang telah distudentized (Ghozali, 2011: 139). Dasar pengambilan keputusan :

1) Jika ada pola tertentu, seperti titik-titik yang ada membentuk pola tertentu yang teratur (bergelombang, melebar kemudian menyempit), maka mengindikasikan telah terjadi heterokedastisitas.

2) Jika tidak ada pola yang jelas, serta titik-titik menyebar di atas dan di bawah angka 0 pada sumbu Y, maka tidak terjadi heteroskesdastisitas (Imam Ghozali, 2011: 139).

2) Pengujian Hipotesis

a. Koefisien Determinasi $\left(\mathrm{r}^{2}\right)$

Koefisien determinasi digunakan untuk mengukur pengaruh variabel-variabel independen terhadap variabel dependen yang nilainya berada di antara 0 sampai 1 . Secara verbal, $r^{2}$ mengukur proporsi atau persentasi dari variasi total pada Y yang dijelaskan oleh model regresi. Batasannya adalah $0 \leq \mathrm{r}^{2} \leq 1$. Jika ${ }^{2}$ bernilai 1 , artinya kesesuaian garisnya tepat, jika $\mathrm{r}^{2}$ bernilai 0 artinya tidak ada hubungan antara regresan dan regresor.

b. Uji Parsial(Uji t)

Uji t digunakan untuk menguji apakah variabel bebas berpengaruh secara signifikan terhadap variabel terikat atau tidak. Dalam penelitian ini, hipotesis yang digunakan adalah:

Ho $: b=0$; Terdapat pengaruh tidak signifikan antara variabel inflasi terhadap nilai tukar Rupiah.

$\mathrm{H} 1: \mathrm{b} \neq 0$; Terdapat pengaruh signifikan antara variabel inflasi terhadap nilai tukar Rupiah.

Dasar pengambilan keputusannya adalah dengan menggunakan taraf signifikan, yaitu:

1) Apabila taraf signifikansi hasil $>$ taraf signifikan yang disyaratkan $(\alpha=5 \%)$, maka $\mathrm{H}_{0}$ diterima dan $\mathrm{H}_{1}$ ditolak.

2) Apabila taraf signifikansi hasil < taraf signifikan yang disyaratkan $(\alpha=5 \%)$, maka $\mathrm{H}_{0}$ ditolak dan $\mathrm{H}_{1}$ diterima. 


\section{HASIL DAN PEMBAHASAN}

\section{Gambaran Umum Lokasi Penelitian}

Berdasarkan pasal 4 ayat 1 Undangundang RI No. 23 Tahun 1999 tentang Bank Indonesia dijelaskan bahwa Bank Indonesia merupakan bank sentral Republik Indonesia. Bank Indonesia adalah lembaga yang independen yang bebas dari campur tangan pemerintah dan/atau pihak-pihak lainnya. Selaku bank sentral, Bank Indonesia memiliki tujuan yaitu untuk mencapai dan memelihara kestabilan nilai rupiah. Tujuan Bank Indonesia untuk mencapai dan memelihara kestabilan nilai rupiah tersebut perlu ditopang dengan tiga pilar utama yaitu kebijakan moneter dengan prinsip kehatihatian, sistem pembayaran yang cepat dan tepat serta sistem perbankan dan keuangan yang sehat.

\section{Analisis Statistik Deskriptif}

Statistik deskriptif digunakan untuk mendeskripsikan atau menggambarkan data yang diteliti. Statistik deskriptif memudahkan pengamatan melalui penghitungan data, rata-rata data, serta standart deviasi sehingga diperoleh gambaran data-data hasil penelitian secara menyeluruh.

Terdapat dua variabel yang akan dianalisis dalam penelitian ini, yaitu nilai tukar Rupiah sebagai variabel terikat dan tingkat inflasi sebagai variabel bebas. Pengukuran statistik deskriptif pada penelitian ini dilakukan dengan memanfaatkan program MS Windows Excel 2007.

Dari hasil perhitungan statistik deskriptif menunjukkan bahwa statistik deskriptif dari sampel penelitian dimana periode pengujian sampel dalam penelitian ini dilakukan pada suatu periode pengamatan yang berkelanjutan (time series) selama lima tahun yaitu pada bulan Januari
2011 hingga Desember 2015. Deskripsi data dari masing-masing variabel penelitian adalah sebagai berikut:

1. Tingkat Inflasi $\left(\mathrm{X}_{1}\right)$

Tingkat inflasi di Indonesia pada bulan Januari 2011 hingga bulan Desember 2015 cenderung berfluktuasi. Variabel tingkat inflasi (X1) mengalami titik tertinggi pada $8,79 \%$ pada bulan Agustus tahun 2013, dan mengalami titik terendah mencapai 3,35\% pada bulan Desember tahun 2015. Sedangkan nilai rata-rata variabel tingkat inflasi sebesar 5,88\%. Nilai standart deviasi tingkat inflasi sebesar 1,54\%, hal ini menunjukkan bahwa penyebaran data tingkat inflasi masih dalam taraf normal karena tidak melebihi nilai rata-ratanya.

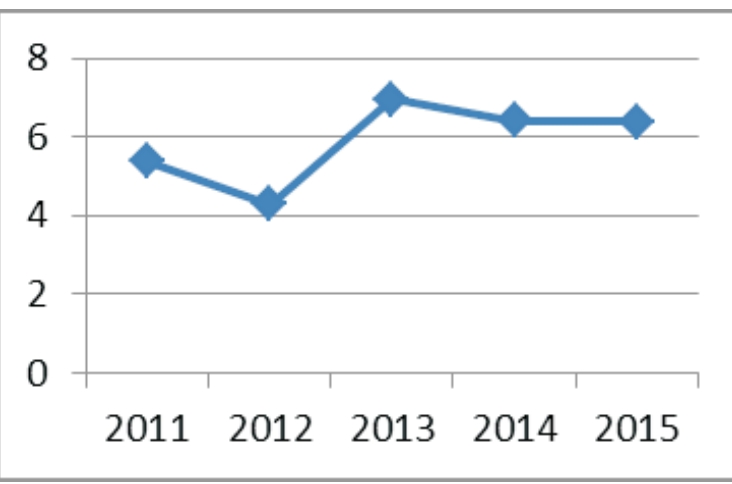

Nilai rata-rata tingkat inflasi pada tahun 2011 sebesar 5,38\%, kemudian pada tahun 2012 rata-rata tingkat inflasi mengalami penurunan hingga 4,28\%. Pada tahun 2013 rata-rata tingkat inflasi meningkat hingga $6,97 \%$, namun pada tahun 2014 dan 2015 rata-rata tingkat inflasi mengalami penurunan sebesar $0,55 \%$ yaitu rata-rata inflasi tahun 2014 sebesar 6,42\%. Penurunan ini diikuti tahun berikutnya yaitu tahun 2015 yang berada pada posisi 6,38\%.

2. Nilai Tukar Rupiah

Rata-rata nilai tukar Rupiah terhadap Dollar selama lima tahun terakhir cenderung mengalami depresiasi 
namun pada tahun 2015 nilai tukar Rupiah mengalami apresiasi terhadap mata uang dollar AS. Rata-rata nilai tukar selama lima tahun terakhir ini yaitu Rp 9.925,89/USD dengan titik tertinggi sebesar $\mathrm{Rp} 11.135,70 / \mathrm{USD}$ terjadi pada bulan Juni tahun 2014, dan berada pada titik terendah terjadi pada bulan Maret tahun 2010 yaitu sebesar Rp 8.851,10/USD.

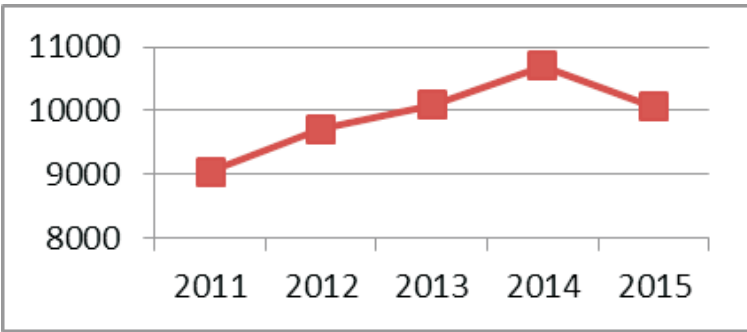

Rata-rata nilai tukar pada tahun 2011 sebesar Rp 9.048,41/USD, kemudian tiga tahun berikutnya yaitu pada tahun 2012-2014 nilai tukar Rupiah mengalami depresiasi dengan rata-rata masing-masing sebesar $\mathrm{Rp}$ 9.719,41; Rp 10.092,99; Rp 10.704,68 per US dollar (USD). Pada tahun 2015 nilai tukar Rupiah mengalami apresiasi dengan rata-rata sebesar Rp 10.063,96/USD.

\section{Hasil Analisis Regresi Linier Sederhana}

Model regresi linier sederhana digunakan untuk menghitung seberapa besar pengaruh antara variabel bebas yaitu tingkat inflasi $(\mathrm{X})$ terhadap variabel terikat yaitu nilai tukar Rupiah (Y).

Hasil perhitungan koefisien regresi dengan menggunakan program SPSS 22.0 sehingga didapat model regresi sebagai berikut:

\section{Coefficients $^{\text {a }}$}

\begin{tabular}{|c|c|c|c|c|c|}
\hline \multirow[b]{2}{*}{ Model } & \multicolumn{2}{|c|}{$\begin{array}{c}\text { Unstandardized } \\
\text { Coefficients } \\
\end{array}$} & \multirow{2}{*}{$\begin{array}{c}\begin{array}{c}\text { Standardized } \\
\text { Coefficients }\end{array} \\
\text { Beta } \\
\end{array}$} & \multirow[b]{2}{*}{$\mathrm{t}$} & \multirow[b]{2}{*}{ Sig. } \\
\hline & B & $\begin{array}{c}\text { Std. } \\
\text { Error }\end{array}$ & & & \\
\hline 1 (Constant) & 3,941 &, 023 & & 173,962 &, 000 \\
\hline Inflasi &, 073 & ,030 & ,307 & 2,456 &, 017 \\
\hline
\end{tabular}

\section{a. Dependent Variable: Kurs}

Berdasarkan pada Tabel di atas didapatkan persamaan model regresi linear sederhana sebagai berikut:

$$
\mathrm{Y}=3,941+0,073 \mathrm{X}
$$

Dari persamaan di atas dapat diinterpretasikan bahwa jika tidak terdapat perubahan variabel tingkat inflasi (X = tetap), dengan kata lain, nilai tukar Rupiah akan meningkat sebesar 3,941 poin dalam satu bulan tanpa adanya pengaruh dari tingkat inflasi. Koefisien variabel tingkat inflasi pada persamaan adalah sebesar 0,073 . Hal ini berarti, apabila tingkat inflasi mengalami peningkatan $1 \%$, maka nilai tukar Rupiah akan meningkat sebesar 0,073 . Begitu pun sebaliknya, apabila tingkat inflasi mengalami penurunan $1 \%$ maka akan menyebabkan nilai tukar Rupiah juga menurun sebesar 0,073.

\section{Hasil Pengujian Asumsi Klasik}

\section{Uji Normalitas}

Uji normalitas bertujuan untuk menguji apakah dalam model regresi, variabel pengganggu atau residul memiliki distribusi normal atau tidak. Pengujian asumsi uji normalitas dalam penelitian ini dilakukan dengan 
menggunakan program Statistic Package for Social Science (SPSS) 22.0 for MS Windows.
Hasil uji normalitas dapat dilihat pada gambar berikut:

\section{Normal P-P Plot of Regression Standardized Residual}

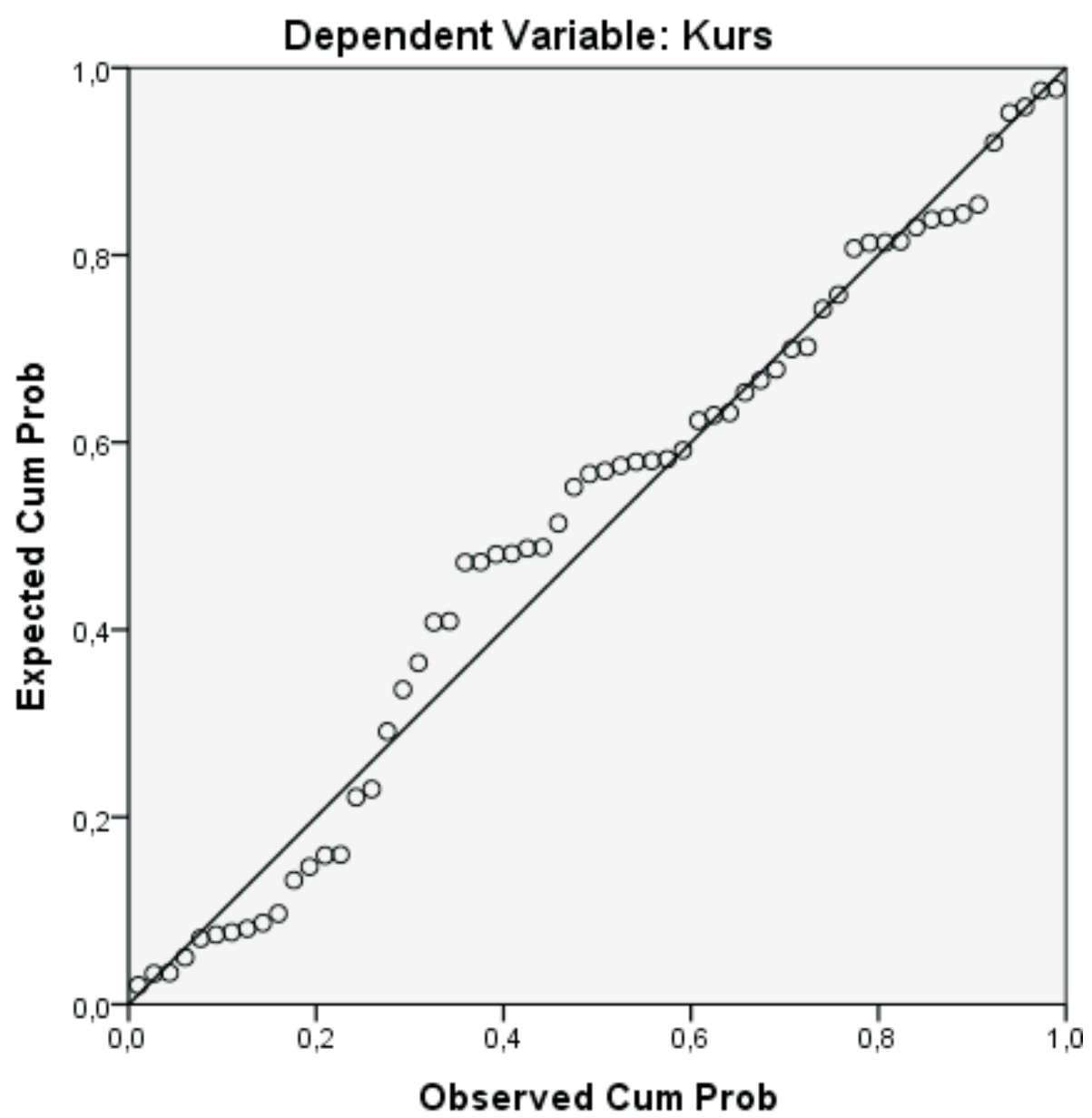

Berdasarkan gambar di atas, terlihat titik-titik menyebar di sekitar garis diagonal dan penyebarannya pun mengikuti arah garis diagonal tersebut. Sehingga dapat disimpulkan bahwa model regresi dalam penelitian ini uji normalitas data telah terpenuhi.

2. Uji Autokorelasi

Uji autokorelasi bertujuan untuk menguji apakah dalam model regresi linier terdapat korelasi antara kesalahan pengganggu (residual) pada periode $\mathrm{t}$ dengan kesalahan pengganggu pada periode t-1 (sebelumnya).

Pengujian ada tidaknya autokorelasi dilakukan dengan mengguna- kan uji Durbin-Watson (DW test). Dari tabel statistik Durbin-Watson, ditentukan bahwa untuk jumlah sampel $n=60$, jumlah variabel bebas $\mathrm{k}=1$, dan taraf signifikan $\alpha=5 \%=0,05$, diperoleh batas atas yaitu $\mathrm{d}_{\mathrm{U}}$ sebesar 1,616 dan batas bawah yaitu $\mathrm{d}_{\mathrm{L}}$ sebesar 1,549.

Hasil perhitungan uji autokorelasi dengan menggunakan program SPSS 22.0 dapat dilihat pada tabel berikut:

\begin{tabular}{|c|c|}
\hline Model & Durbin-Watson \\
\hline 1 &, 189 \\
\hline
\end{tabular}


Berdasarkan batas atas dan batas bawah yang diperoleh dari tabel statistik Durbin-Watson, maka daerah tidak adanya autokorelasi adalah antara $\mathrm{d}_{\mathrm{U}}$ sampai $4-\mathrm{d}_{\mathrm{U}}$, yaitu di antara nilai 1,641 sampai 2,384. Berdasarkan hasil perhitungan, nilai Durbin-Watson diperoleh sebesar 0,189 maka dapat disimpulkan bahwa dalam pendugaan model regresi terjadi autokorelasi atau terjadi problem autokorelasi.

Hal ini dikarenakan salah satu ciri data time series dalam fenomena ekonomi yaitu kelembaman yaitu data observasi pada periode sebelumnya dan periode sekarang, kemungkinan besar mengandung saling ketergantungan. Selain itu tidak dimasukkannya variabel bebas yang mempengaruhi nilai tukar Rupiah di luar penelitian ini menyebabkan adanya unsur pengganggu yang akan merefleksikan suatu pola yang sistematis di antara sesama unsur pengganggu sehingga terjadi situasi autokorelasi di antara unsur pengganggu (Suliyanto, 2011:125).

3. Uji Heteroskedastisitas

Tujuan dari adanya uji heterokedastisitas yaitu untuk menguji apakah dalam model regresi terjadi ketidaksamaan variance dari residual satu pengamatan ke pengamatan lain. Ada atau tidaknya heterokedastisitas dideteksi dengan melihat ada tidaknya pola tertentu pada grafik scatter plot antara SRESID dan ZPRED dimana sumbu $Y$ adalah $Y$ yang telah diprediksi, dan sumbu $\mathrm{X}$ adalah residual yang telah di-studentized.

Hasil penggambaran grafik Scatter Plot dengan menggunakan program SPSS 22.0 adalah sebagai berikut:

\section{Scatterplot}

\section{Dependent Variable: Kurs}

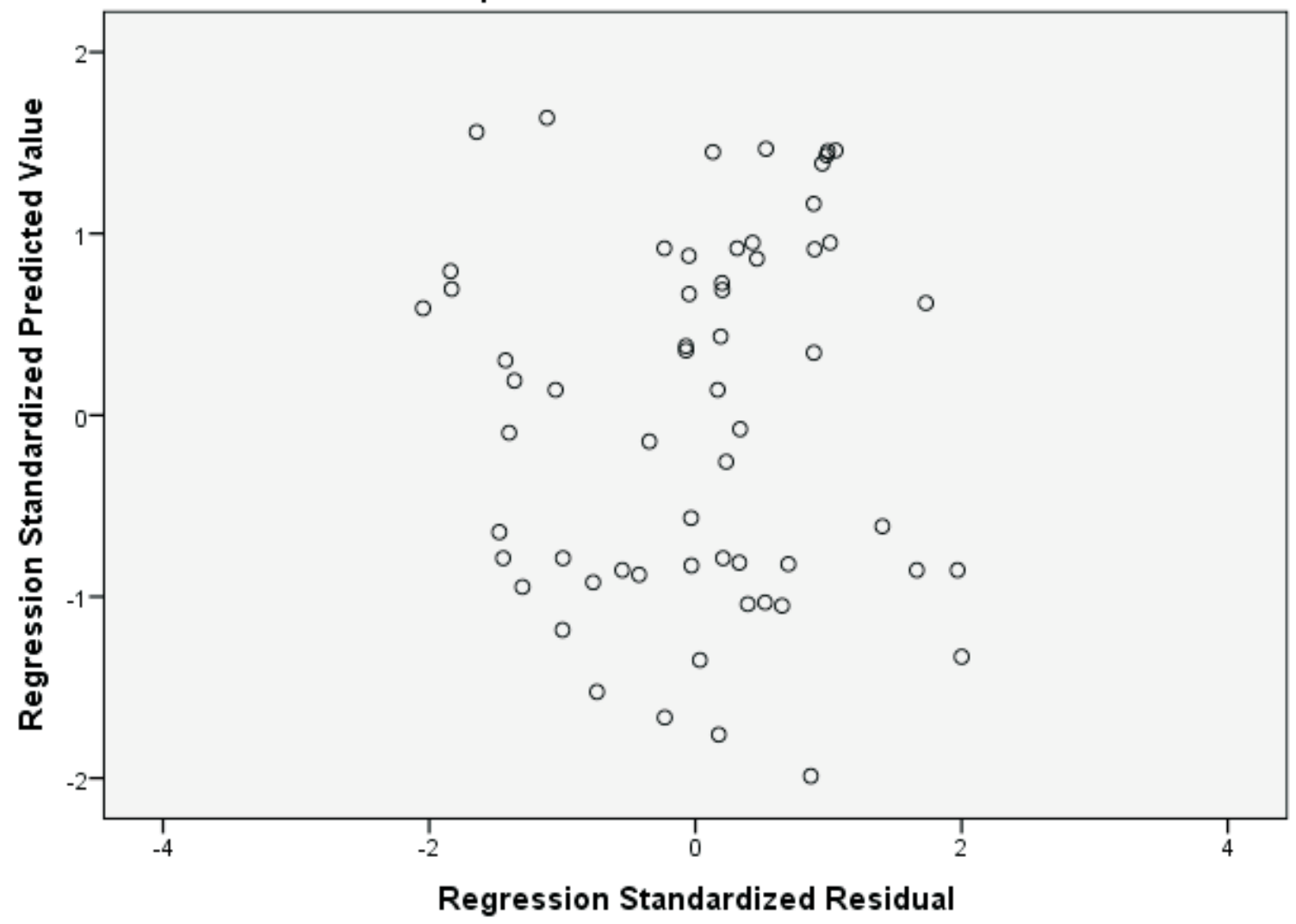


Dari grafik Scatter Plot dalam penelitian ini terlihat bahwa titik-titik menyebar secara acak dan tidak membentuk pola tertentu. Sehingga hal ini dapat disimpulkan bahwa dalam pendugaan model regresi tidak terjadi heterokedastisitas.

\section{PENUTUP}

\section{Simpulan}

\section{Tingkat Inflasi}

Berdasarkan hasil penelitian yang telah dilakukan dapat diketahui bahwa tingkat inflasi di Indonesia pada bulan Januari 2011 hingga bulan Desember 2015 cenderung berfluktuasi. Variabel tingkat inflasi (X1) mengalami titik tertinggi pada $8,79 \%$ pada bulan Agustus tahun 2013, dan mengalami titik terendah mencapai 3,35\% pada bulan Desember tahun 2015. Sedangkan nilai rata-rata variabel tingkat inflasi sebesar 5,88\%. Nilai standart deviasi tingkat inflasi sebesar 1,54\%, hal ini menunjukkan bahwa penyebaran data tingkat inflasi masih dalam taraf normal karena tidak melebihi nilai rata-ratanya.

\section{Nilai Tukar Rupiah}

Ditinjau dari hasil penelitian yang telah dilakukan, rata-rata nilai tukar Rupiah terhadap Dollar selama lima tahun terakhir cenderung mengalami depresiasi namun pada tahun 2015 nilai tukar Rupiah mengalami apresiasi terhadap mata uang dollar AS. Rata-rata nilai tukar tukar selama lima tahun terakhir ini yaitu $\mathrm{Rp}$ 9.925,89/USD dengan titik tertinggi sebesar Rp 11.135,70/USD terjadi pada bulan Juni tahun 2014, dan berada pada titik terendah terjadi pada bulan Maret tahun 2010 yaitu sebesar Rp $8.851,10 /$ USD.
3. Pengaruh Tingkat Inflasi terhadap Nilai Tukar Rupiah

Berdasarkan hasil dari penelitian yang telah diteliti mengenai pengaruh tingkat inflasi terhadap nilai tukar Rupiah periode Januari 2011 sampai dengan 2015 dengan menggunakan teknik analisis regresi linier sederhana, maka dapat diambil kesimpulan yaitu tingkat inflasi berpengaruh positif secara signifikan terhadap nilai tukar Rupiah. Hal ini ditunjukkan oleh nilai taraf signifikan yang dihasilkan sebesar 0,017 lebih kecil dari taraf signifikan yang diisyaratkan yaitu 0,05 . Berdasarkan hasil uji koefisien determinasi $\left(\mathrm{R}^{2}\right)$ menunujukkan bahwa nilai tukar Rupiah dipengaruhi oleh tingkat inflasi sebesar 7,9\%. Hal ini mengartikan bahwa perubahan nilai tukar Rupiah dipengaruhi oleh variabel tingkat inflasi. Sedangkan sisanya sebesar 92,1\% dipengaruhi oleh faktor-faktor lain yang tidak diteliti oleh peneliti. Hal ini sesuai dengan teori paritas daya beli yang merupakan ekpektasi perubahan kurs terjadi karena adanya perbedaan tingkat inflasi.

\section{Saran}

Berdasarkan simpulan di atas, maka dapat dikemukakan beberapa saran yang diharapkan dapat bagi Indonesia ataupun bagi pihak-pihak lain. Adapun saran-saran yang diberikan antara lain:

1. Sebagai bank sentral, Bank Indonesia diharapkan dapat berhati-hati dalam mengambil dan mengeluarkan kebijakan di bidang moneter dan mengantisipasi terhadap krisis ekonomi yang terjadi di dunia agar selalu memperhatikan laju inflasi yang telah ditetapkan. Sehingga tujuan utama dari Bank Indonesia yaitu mencapai dan memelihara kestabilan nilai Rupiah dapat tercapai demi meningkatnya pertumbuhan ekonomi di Indonesia. 
2. Pemerintah diharapkan lebih memperhatikan kebijakan-kebijakan yang terkait dengan perekonomian secara makar untuk menjaga kestabilan nilai tukar Rupiah, dimana perubahan tingkat inflasi merupakan salah satu faktor makro ekonomi yang cenderung mempengaruhi pergerakan nilai tukar Rupiah terhadap mata uang negara lain. Karena jika tingkat inflasi Indonesia tinggi, maka akan mengakibatkan terdepresiasinya nilai tukar Rupiah terhadap mata uang negara lain. Begitu pula sebaliknya apabila tingkat inflasi Indonesia rendah maka nilai tukar Rupiah akan terapresiasi.

3. Diharapkan penelitian ini dapat dipakai sebagai acuan bagi peneliti selanjutnya untuk mengembangkan penelitian ini dengan mempertimbangkan variabelvaribel lain yang tidak dimasukkan dalam penelitian ini mengingat variabel bebas dalam penelitian ini merupakan faktor terpenting dalam mempengaruhi nilai tukar Rupiah. Serta peneliti selanjutnya dapat mengambil sampel yang lebih terperinci atau sampel dari kategori lain karena dalam penelitian ini menggunakan sampel Bank Indonesia secara keseluruhan.

\section{DAFTAR PUSTAKA}

Boediono. 2013. Seri Sinopsis Pengantar Ilmu Ekonomi No. 5. Ekonomi Moneter. Yogyakarta: BPFE.

Faisal, M. 2001. Manajemen Keuangan Internasional. Jakarta: Salemba Empat.

Ghozali, Imam. 2011. Aplikasi Analisis Multivariate Dengan Program IBM SPSS 19. Cetakan Kelima. Semarang: Badan Penerbit Universitas Diponegoro.
Kartikaningtyas, Nisita. 2014. Pengujian Teori Paritas Daya Beli Nilai Tukar Empat Mata Uang Utama Terhadap Rupiah Indonesia. Jurnal Administrasi Bisnis Vol. 10 No. 1. Malang, Mei 2014.

Madura, Jeff. 2006. International Corporate Finance Keuangan Perusahaan Internasional. Jakarta: Salemba Empat.

Mankiw, Gregory N. 2012. Pengantar Ekonomi Makro. Jakarta: Salemba Empat.

Nasution. 2012. Metode Research: Penelitian Ilmiah. Edisi Pertama. Cetakan Ketigabelas. Jakarta: Bumi Aksara.

Nopirin. 2013. Ekonomi Moneter. Buku Dua Edisi Pertama. Yogyakarta: BPFE.

Pupitaningrum, Roshinta. Pengaruh Tingkat Inflasi, Tingkat Suku Bunga SBI, dan Pertumbuhan Ekonomi Terhadap Nilai Tukar Rupiah Studi Pada Bank Indonesia Periode Tahun 2003-2012. Jurnal Administrasi Bisnis Vol. 8 No. 1. Malang, Februari 2014.

Sugiyono, Prof. Dr. 2013. Metode Penelitian Kuantitatif, Kualitatif, dan Kombinasi (Mixed Methods). Bandung: Alfabeta.

Sukirno, Sadono. 2013. Makro Ekonomi Teori Pengantar. Jakarta: Rajawali Pers.

Suliyanto. 2011. Ekonometrika Terapan: Teori \& Aplikasi dengan SPSS. Yogyakarta: Andi.

Undang-Undang Nomor 23 Tahun 1999 tentang Bank Indonesia.

Yuliati, Sri Handayani dan Prasetyo, Handoyo. 2005. Dasar-dasar Manajemen Keuangan Internasional. Yogyakarta:Andi. 